\title{
EM TUA CASA DESERTA
}

TRADUZIDO POR GEYLSON ALVES 


\title{
EM TUA CASA DESERTA
}

\author{
Traduzido por \\ Geylson ALVES ${ }^{1}$ \\ Licenciado em Letras pela Universidade Federal de Campina Grande (UFCG) \\ Campina Grande, Paraíba, Brasíl \\ geylsonalves@gmail.com
}

\section{En tu casa desierta}

El alma llena de recogimiento, mudos los labios, me detengo en cada lugar de tu mansión, ensimismada cual si la fatigase un pensamiento.

El naranjo medita. En el momento en que estoy en tu alcoba, la almohada me dice que en la noche prolongada

\section{Em tua casa deserta}

A alma plena de recolhimento, mudos os lábios, me detenho em cada lugar de tua mansão, ensimesmada como se a fatigasse um pensamento.

O laranjal medita. No momento em que estou em tua alcova, a almofada me diz que na noite prolongada teu rosto tíbio lhe dará alento.

Profunda é a paz... Mas a angústia cresce ao olhar que nos voltas. Faz um ruído o vento entre as folhas, e parece

que no pátio se queixam os defuntos... É o laranjal, que ao temer teu olvido está me convidando a que choremos juntos!

\section{REFERÊNCIA BIBLIOGRÁFICA}

LÓPEZ VELARDE, Ramón. En tu casa desierta. In: . Obra poética. Coord. José Luis Martínez. Ed. crítica. Madrid: ALLCA XX, 1998. p. 40. (Colección Archivos, 36)

\footnotetext{
${ }^{1}$ Lattes Geylson Alves. Disponível em: http://lattes.cnpq.br/2803070976398954
}

RECEBIDO EM: 12 de setembro de 2015

ACEITO EM: 26 de novembro de 2015 